\title{
Partners in financial literacy Outreach to student entrepreneurs
}

$I^{\mathrm{n}}$ 2018, small businesses employed 58.9 million Americans, totaling $47.5 \%$ of the U.S. private workforce. ${ }^{1}$ Libraries often play a central role in helping people make their entrepreneurial dreams a reality by providing resources to support the research that goes into developing, running, and expanding small businesses. Public libraries are traditional resource centers for small business, but universities and academic libraries are increasingly supporting student entrepreneurs through both curricular and extracurricular programming to help them develop new startups and small businesses. Though libraries are instrumental in providing access to business development information, they may miss a key service area for successful entrepreneurship—financial literacy programming.

\section{Financial literacy and entrepreneurship}

When you think of small business development, market research and business models might first come to mind, but financial literacy and personal finances play a large role in the business planning process. Financial literacy is key in keeping an enterprise afloat at all stages, according to experts.

CB Insights, a venture capital database, reviewed 101 failed startups and found "running out of cash" was the second most common reason for venture failure. ${ }^{2}$

In a case study, the Small Business Development Center at the University of South Florida found that owners of financially distressed companies in their sample did not conduct monthly financial analysis on their business's financial statements. Further, these business owners were also very unlikely to review their monthly financial statements at all or to understand the concepts of key business ratios that give insight into an enterprise's performance. ${ }^{3}$ These findings point to the importance of financial management skills for entrepreneurs, which is an area that libraries can work with expert partners to address.

Even well-resourced small business development programs may lack a financial literacy component. Invent Penn State, the statewide entrepreneurial initiative of Penn State University, provides access to experienced business professionals, training, funding, and "Innovation Hubs, ${ }^{\text {4 }}$ but it does not have a formalized financial literacy component.

Inside the classroom, the Penn State Entrepreneurship and Innovation (ENTI) minor provides courses in nine areas of entrepreneurial interest, ${ }^{5}$ but none specifically in accounting, personal finance, or other areas of importance to small business finance. Financial literacy programs offered by libraries are one way to address this gap and connect student entrepreneurs with the business community and organizations that can help them with the

Emily Mross is business librarian and library outreach coordinator at Penn State-Harrisburg Library, email: elm43@psu.edu, and Lauren Reiter is business liaison librarian at Penn State-University Park, email: Imr29@ psu.edu

๑ 2019 Emily Mross and Lauren Reiter 
financial aspects of their business plans and eventual ventures.

The Penn State University Libraries play an active role in the academic entrepreneurial community by directly supporting both Invent Penn State and the ENTI minor through an action team that coordinates collection materials purchases, research guide development, and instruction sessions. The team also promotes librarian engagement with students, faculty, and community members in all stages of the small business development process through their campus libraries.

In addition to traditional entrepreneurship support, the University Libraries and Penn State University provide programming and resources to promote financial literacy through in-person and online workshops, financial literacy education modules, and personal finance books in the library collections.

University Libraries 2019 Startup Week and Money Smart Week Events Tuesday-Thursday, April 2-4 Pattee Library and Paterno Library Tours, panel discussions, and featured speaker presentations

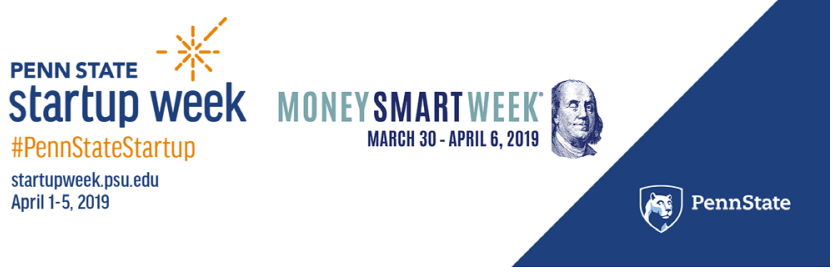

Promotional image for University Libraries Startup Week events at University Park.

In 2019, to address the entrepreneurial financial literacy education gap and to build connections between student entrepreneurs and available financial literacy resources, the action team piloted workshops during Penn State Startup Week at the University Park and Harrisburg campuses.

\section{Penn State Startup Week}

Startup Week is an event across Penn State campuses consisting of presentations, workshops, and networking opportunities related to entrepreneurship and innovation. ${ }^{6}$ Programming at each campus is in-person with some programming available university-wide online through Zoom. Examples of Startup Week events include pitch competitions for students, networking receptions with alumni
University Park programs

Pattee-Paterno Library at Penn State University Park hosted two programs, both developed and delivered by a business consultant from the Penn State Small Business Develop-

who work in the startup environment, and talks by experienced entrepreneurs.

Smart Week, a time to promote financial literacy in communities across the United States. In addition to financial literacy programming, Penn State University Libraries contributed to the week's programming by offering tours of the library's media and maker technologies, a session on intellectual property for creative entrepreneurs, and business planning resources.

ment Center (SBDC). SBDC offers free one-onone business consulting to aspiring and established community and student entrepreneurs, primarily serving Centre and Mifflin counties in Central Pennsylvania. ${ }^{7}$ It is one of nearly 1,000 SBDCs serving local communities across the United States. ${ }^{8}$ Penn State SBDC emphasizes unbiased business consultation, confidentiality provided to clients, and, ultimately, its role as an educational program.

In addition to one-on-one assistance, the Penn State SBDC offers seminars that cover the steps to starting a business, including financing. After a meeting to discuss the library's interest in financial literacy programming for entrepreneurs, the SBDC consultant designed two customized sessions: Financial Preparation for Startups, intended for entrepreneurs in the early stages of developing a business idea, and Financial Analysis to Grow Your 
Business, developed for more established entrepreneurs looking to delve more deeply into the financial side of business.

Financial Preparation for Startups covered different types of financing options, such as grants, bank loans, and angel investing, as well as the components of the credit score and other measures of credit worthiness. It also explored business structure options and related tax considerations, and the steps for preparing a business plan, including estimating revenues and other information for the financial plan.

Financial Analysis to Grow Your Business covered financing and business plans with a focus on how ratio analysis and other financial tools can help businesses determine their worth and grow.

It was easy to work with SBDC to plan these two well-attended sessions. Initial registration counts for both workshops were fairly low, but turnout far exceeded expectations, with 36 attendees at Financial Preparation for Startups and 13 at Financial Analysis to Grow Your Business, the more advanced session. Marketing efforts included the Startup Week online scheduler and the library's social media platforms. Instructors also encouraged or required their students to attend Startup Week sessions, which also likely contributed to the higher-than-anticipated attendance. Both sessions concluded with an invitation to make a one-on-one appointment with SBDC, so that students could follow-up with questions and learn more.

\section{Penn State Harrisburg program}

The Penn State Harrisburg Library collaborated with the Pennsylvania State Educators Credit Union (PSECU), a Harrisburg-based, statewide credit union that regularly delivers financial education sessions in the workplace, for schools, and community organizations. ' We developed the content based on input from the campus Entrepreneurship Club, one of the cosponsors of Startup Week programming at Penn State-Harrisburg. Targeted to students with ideas for a small business, or who were in the early stages of writ- ing a business plan, "Entrepreneurs, Small Business, and Financial Literacy" covered the resources available to help small businesses launch financially, including services offered by SBDCs and the Small Business Administration (SBA). It also addressed the business services generally offered by financial institutions, like loans and lines of credit, and the documentation required of the entrepreneur in order to secure financing.

Though our presenter works for a credit union, she did not promote the products and services of her institution, but instead provided information to prepare entrepreneurs to work with any financial institution. She stressed the impact of personal credit history on business credit worthiness and detailed the documents required to apply for business services, including personal and business income verifications, collateral for loans, and personal and business credit histories.

Working with a financial institution to deliver financial literacy programming provides credibility and a presenter with extensive expertise in the subject matter. Though turnout was relatively low, with nine attendees, they were engaged and stayed after the presentation to ask questions of both the PSECU presenter and the librarian about business support resources. We marketed the program via the Startup Week scheduler, library social media, Entrepreneurship Club social media, targeted emails to entrepreneurship professors, and posters across campus.

\section{Opportunities for growth}

\section{Evaluations}

Both campuses used the same survey to evaluate the sessions, resulting in some shared takeaways. For example, we asked students what steps they have taken in creating a business and provided numerous options from "I have an idea for a business" to "I currently operate my business." All but one individual who answered this question said they were only as far as developing an idea for a business. The outlier had taken the next step of researching a business idea. These survey results, combined with the lower attendance 
at the more advanced session, suggest that introductory programs covering business financing may best serve our students.

The survey also asked students to identify any other financial literacy programs they had attended. The majority had not attended any type of financial literacy program, which may suggest a gap to fill. When asked for suggestions for future financial literacy program topics, one respondent indicated general financial literacy as an area of interest.

\section{Next steps}

Penn State University and the University Libraries will continue to provide general financial literacy programming, as requested by one of the attendees. We will also look for more ways to connect financial literacy to the support we provide for Invent Penn State and

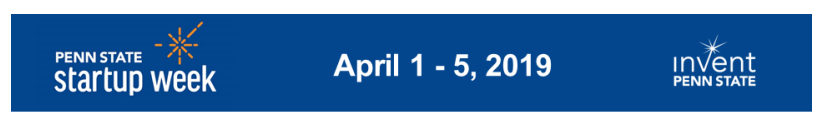

Entrepreneurs, Small Business and Financial Literacy Featuring Sara Weiser from PSECU Tuesday, April $2^{\text {nd }} \bullet 11: 30 \mathrm{am}-12: 30 \mathrm{pm}$ Morrison Gallery (LIB 101) SNACKS WILL BE SERVED REGISTER: bit.ly/psecustartupweek Sponsored by Penn State Harrisburg Library

Lunch with Entrepreneur Peter Sobotta
Featuring Peter Sobotta, Co-Founder \& CEO of ReturnLogic
Thursday, April $4^{\text {th }}$ 11:30 am -12:30 pm
E134 OImsted (behind Stax, across from Housing \& Food Office)
LUNCH WILL BE SERVED • DOOR PRIZES
REGISTER: petersobotta.eventbrite.com
Sponsored by the Entrepreneurship Club. Funded by SAF.

Lunch with Entrepreneur Peter Sobotta Featuring Peter Sobotta, Co-Founder \& CEO of ReturnLogic LUNCH WILL BE SERVED • DOOR PRIZES Sponsored by the Entrepreneurship Club. Funded by SAF.
Hubs, SCORE, and any other small business organizations active in Pennsylvania or in their communities. This creates a network of experts that we can rely on for programming that provides both education and opportunities for building relationships.

For libraries, inviting a community partner to present can make it easier to provide programming on topics outside of your subject expertise. Partners can also help you develop programs that you may not have the time to develop alone. These programs help build stronger ties between the library and the entrepreneurial community and increase the credibility of the academic library as a partner in small business development. Partners and the library can reinforce the expertise and value of each organization as part of the programming.

Finding a partner is as easy as asking. There are likely a number of the ENTI minor, and help

\section{Promotion}

our users make connections to small business development professionals in the local communities near our campuses. There are opportunities to offer additional financial literacy programming for entrepreneurs during Global Entrepreneurship Week, celebrated in November.

\section{Working with partners}

A community partner who provided trustworthy, real-world expertise for students made programming at each campus possible. Entrepreneurship programs at Penn State similarly emphasize the importance of community partnerships in small business development. Student entrepreneurs are encouraged to work with SBDCs, Innovation organizations in your community that already offer the kinds of programming you hope to provide. Have an idea of the information your students need, and ask if it is a program they currently offer or could develop. Financial institutions frequently offer financial education sessions as part of the Community Reinvestment Act, and organizations like SBDCs offer regular programming for entrepreneurs.

In addition to community partners, seek student organizations and faculty to help guide the programming and promote it. Building bridges does not only occur off campus. Unexpected services might mean unexpected new visitors at your library who need your help to realize their business dreams. 


\section{Notes}

1. Small Business Administration Office of Advocacy, "United States Small Business Economic Profiles for 2018," 2018, https://www.sba.gov/sites/default/files /advocacy/2018-Small-Business-Profiles-US. pdf.

2. CB Insights, "The Top 20 Reasons Startups Fail," (February 2, 2018), https:// app.cbinsights.com/research/startup-failure -reasons-top/.

3. Pearl Dahmen and Eileen Rodríguez, "Financial Literacy and the Success of Small Businesses: An Observation from a Small Business Development Center," Numeracy 7, no. 1 (2014), https://doi.org/10.5038/1936 -4660.7 .1 .3 .
4. Invent Penn State, "Impact," 2019, https://invent.psu.edu/impact/.

5. Penn State University, "Intercollege Minor in Entrepreneurship and Innovation," accessed May 13, 2019, enti.psu.edu/.

6. Ibid. "Penn State Startup Week," 2019, https://startupweek.psu.edu/.

7. Penn State Small Business Development Center, accessed June 4, 2019, https://sbdc. psu.edu/.

8. America's Small Business Development Centers, accessed May 30 2019, https:// americassbdc.org/.

9. Pennsylvania State Educators Credit Union, 2019, "Wallet Works Financial Education," https://www.psecu.com/learn /wallet-works. $\approx$

("Making research visible," cont. from page 572)

creative modes of communication might help his research impact new audiences in meaningful ways.

A third competition participant observed that creating a visualization in a new medium helped her tackle her feelings of imposter syndrome and gave her courage on her journey to becoming a university professor.

As library collections and services evolve, we will need to continue to think of new ways to engage with the communities we serve. Making the process of research more visible through a visualize your bibliography competition is one creative way to encourage scholarly communities to engage with their sources, reflect on the connections they have made to past scholarship, and share tangible outputs with the academic community.

\section{Notes}

1. "National Conference on Graduate Services Kennesaw State University," accessed May 22, 2019, https://digitalcommons. kennesaw.edu/gradlibconf/.

2. "ACRL Academic Library Services for Graduate Students Interest Group," accessed
May 22, 2019, https://acrl.libguides.com /als4gsig.

3. "Oregon State University Library Undergraduate Research Awards," accessed May 15, 2019, https://library.oregonstate.edu /awards/undergrad-research.

4. "Penn State University Libraries Undergraduate Research Award," accessed May 15, 2019, https:// libraries.psu.edu/about/awards-scholarships -internships-and-graduate-assistantships /university-libraries-undergraduate.

5. "Library Research Award for Undergraduates - University of Washington Libraries," accessed May 15, 2019, http://www.lib. washington.edu/researchaward.

6. "USC Libraries Research Award," accessed May 15, 2019, https://libraries. usc.edu/locations/special-collections/usc -libraries-research-award.

7. "Brandeis University Research Excellence Prize," accessed May 15, 2019 , http://www.brandeis.edu/library/research /research-excellence-prize.html.

8. LibGuide, https://guides.library. oregonstate.edu/gradcompetition.

9. See https://guides.library.oregonstate. edu/gradcompetition/onlinegallery. $\boldsymbol{n}$ 